\title{
STRATEGI PROMOSI PARIWISATA PROVINSI GYEONGGI DI KOREA SELATAN UNTUK MENARIK WISATAWAN INDONESIA
}

\author{
Kang Hyeonseock \\ Universitas Udayana
}

\begin{abstract}
Abstrack
This study aims to identify the effective promotion strategies on tourism of Gyeonggi Province toward Indonesian tourists who wish to visit Korea. The research location was set in the two countries, namely Korea (Gyeonggi Province) and Indonesia (Jakarta and Bali). The results shows that nowadays, most Indonesian tourists are using travel packages, while $52.5 \%$ of respondents wanted to visit Korea by way of personal travel in the future. Interesting tourist attraction for Indonesian tourists, among others: DMZ (38.2\%), English Village (31.6\%), Everland (30.3\%) and types of tourism such as travel education (33.8\%), meditation (20\%), medical (15\%) also attracts people of Indonesia. Promotion strategies on tourism of Gyeonggi Province is expected to be held through three approaches, including; First, direct cooperation between travel agents through the help of 'B to B' and 'Fam Tour'. Second marketing through a website and social media frequently accessed by the people of Indonesia. Third cooperation between Gyeonggi Provincial Government and Local Government in Indonesia, as well as partnerships with companies and educational institutions in Indonesia.
\end{abstract}

Keywords: Tourism Promotion, Tourism of Gyeonggi, Indonesian Tourists

\begin{abstract}
Abstrak
Penelitian inibertujuan untuk mengidentifikasi strategi promosi yang efektif pada pariwisata dari Provinsi Gyeonggi terhadap wisatawan Indonesia yang ingin mengunjungi Korea. Lokasi penelitian ditetapkan di dua negara, yaitu Korea (Gyeonggi Provinsi) dan Indonesia (Jakarta dan Bali). Hasil penelitian menunjukkan bahwa saat ini, sebagian besar wisatawan Indonesia yang menggunakan paket wisata, sementara 52,5\% responden ingin mengunjungi Korea dengan cara perjalanan pribadi di masa depan. Daya tarik wisata bagi wisatawan Indonesia antara lain: DMZ (38,2\%), English Village (31,6\%),
\end{abstract}


Everland (30,3\%) dan jenis pariwisata seperti perjalanan pendidikan (33,8\%), meditasi (20\%), kesehatan (15 \%) juga menarik orang dari Indonesia. Strategi promosi pariwisata dari Provinsi Gyeonggi diharapkan akan diselenggarakan melalui tiga pendekatan, termasuk; Pertama, kerja sama langsung antara agen perjalanan melalui bantuan 'B to B' dan 'Fam Tour'. Kedua, melalui website dan media sosial sering diakses oleh masyarakat Indonesia. Ketiga, kerja sama antara Pemerintah Provinsi Gyeonggi dan Pemerintah Daerah di Indonesia, serta kemitraan dengan perusahaan dan lembaga pendidikan di Indonesia.

Kata kunci: promosi pariwisata, pariwisata Gyeonggi, Korea, wisatawan Indonesia

\section{Pendahuluan}

Hubungan dan pertukaran warga antara Korea Selatan dan Indonesia semakin meningkat dalam berbagai bidang sejak terjalinnya hubungan diplomatik secara resmi pada tahun 1966. Kerja sama Korea SelatanIndonesia diprioritaskan pada bidang ekonomi, dan sosial budaya. Secara ekonomi, nilai realisasi investasi Korea di Indonesia pada tahun 2013 sebesar USD 2,2 milyar, maka Korea merupakan penanam modal (investor) terbesar keempat yang menanamkan modalnya (capital allocation) di Indonesia selama tahun 2013-2014.

Sementara itu, jika ditinjau dari aspek ketenagakerjaan, pada Januari 2015 terdapat sekitar 35 ribu tenaga kerja asal Indonesia yang bekerja di Korea. Sebaliknya, terdapat sekitar 50 ribu warga negara Korea di Indonesia dengan sekitar 2.500 perusahaan yang bergerak di berbagai bidang industri yang telah menciptakan lapangan pekerjaan bagi masyarakat Indonesia (Korea Trade-Investment Promotion Agency, 2015).

Dalam aspek sosial budaya, fenomena 'Hallyu'sebagai Korean Pop Culture di Indonesia juga menjadi salah satu faktor yang menunjang hubungan masyarakat antara Indonesia dan Korea, baik secara langsung maupun tidak langsung. Sejarah fenomena 'Hallyu' yang muncul sejak awal tahun 2000-an telah menjadikan Korea sebagai negara pengekspor kebudayaan yang sebelumnya hanya merupakan negara pengimpor kebudayaan, bahkan kebanyakan orang sepakat bahwa 'Hallyu' memainkan peranan yang penting dalam perubahan citra Korea di mata dunia internasional. Fenomena ini terlihat di Indonesia, masyarakat Indonesia tertarik dengan 'Hallyu'bahkan mereka mempelajari kebudayaan yang dimiliki oleh negara Ginseng. Dapat dikatakan bahwa 'Hallyu' menjadi faktor pendorong utama evolusi sektor pariwisata Korea Selatan (Suray 2009:6, Riska 2012:5). 
Kebanyakan orang Indonesia mempunyai sudut pandang tentang Korea bahwa daya tarik wisata Korea sangat populer dan menarik. Menurut data Kementerian Pariwisata dan Ekonomi Kreatif Indonesia, pada tahun 2014 jumlah wisatawan Indonesia ke luar negeri sebanyak 7.899 ribu orang yang mengalami sedikit penurunan dibandingkan dengan tahun 2013. Di tahun 2014, jumlah wisatawan asal Indonesia yang mengunjungi Korea adalah 208 ribu orang. Hal ini menunjukan keadaan peningkatan angka kunjungan sebanyak 10,1\% apabila dibandingkan dengan tahun 2013 yang berjumlah 189 ribu orang. Berbanding terbalik dengan jumlah wisatawan Indonesia ke Cina yang mengalami penurunan $6,4 \%$, apabila dibandingkan dengan tahun 2013. Dengan demikian, dapat dikatakan bahwa saat ini wisatawan Indonesia lebih memilih berwisata ke negeri ginseng (Korea) dari pada ke negeri tirai bambu (Cina).

Berdasarkan daya tarik wisata yang dikunjungi, sebagian besar wisatawan Indonesia menjadwalkan perjalanan ke tempat populer seperti Ibu Kota Seoul, pulau Jeju, dan gunung Seorak. Kontradiktif dengan kecenderungan wisatawan asing ke tiga daya tarik tersebut, di Provinsi Gyeonggi wisatawan hanya singgah beberapa jam atau jalur yang dilewati saja. Kebanyakan wisatawan Indonesia belum sempat mengunjungi daya tarik wisata di Provinsi Gyeonggi. Padahal Gyeonggi memiliki daya tarik wisata yang variatif dan menarik seperti Everland, DMZ (DeMilitarized Zone), tempat syuting, dan situs warisan budaya dunia.

Dengan kata lain, tingkat preferensi terhadap daya tarik wisata tersebut masih sangat rendah karena calon wisatawan tidak mempunyai kesempatan untuk memilih produk wisata yang bersangkutan, alasannya karena kesulitan dalam menemukan produk wisata Provinsi Gyeonggi di Indonesia.

Berdasarkan latar belakang di atas maka dirumuskan permasalahan sebagai berikut: Pertama, bagaimana persepsi wisatawan Indonesia terhadap wisata Korea dan Provinsi Gyeonggi? Kedua, bagaimana preferensi wisatawan Indonesia terhadap daya tarik wisata Provinsi Gyeonggi? Ketiga, bagaimana efektivitas promosi pariwisata Provinsi Gyeonggi untuk menarik wisatawan Indonesia?

\section{Teori dan Metode}

Analisis teori SWOT digunakan untuk mengetahui efektifitas program pemasaran dan promosi pariwisata Provinsi Gyeonggi. Teori strategi pemasaran digunakan sebagai formulasi pemasaran pariwisata Gyeonggi melalui tiga indikatornya yaitu segmentasi pasar (segmenting), penetapan target atau sasaran pasar (targeting), penetapan posisi pasar (positioning). Teori strategi promosi digunakan untuk mengusulkan strategi promosi pariwista Gyeonggi yang bertujuan memberikan informasi dan memengaruhi calon wisatawan Indonesia untuk mengambil keputusan dalam memilih 

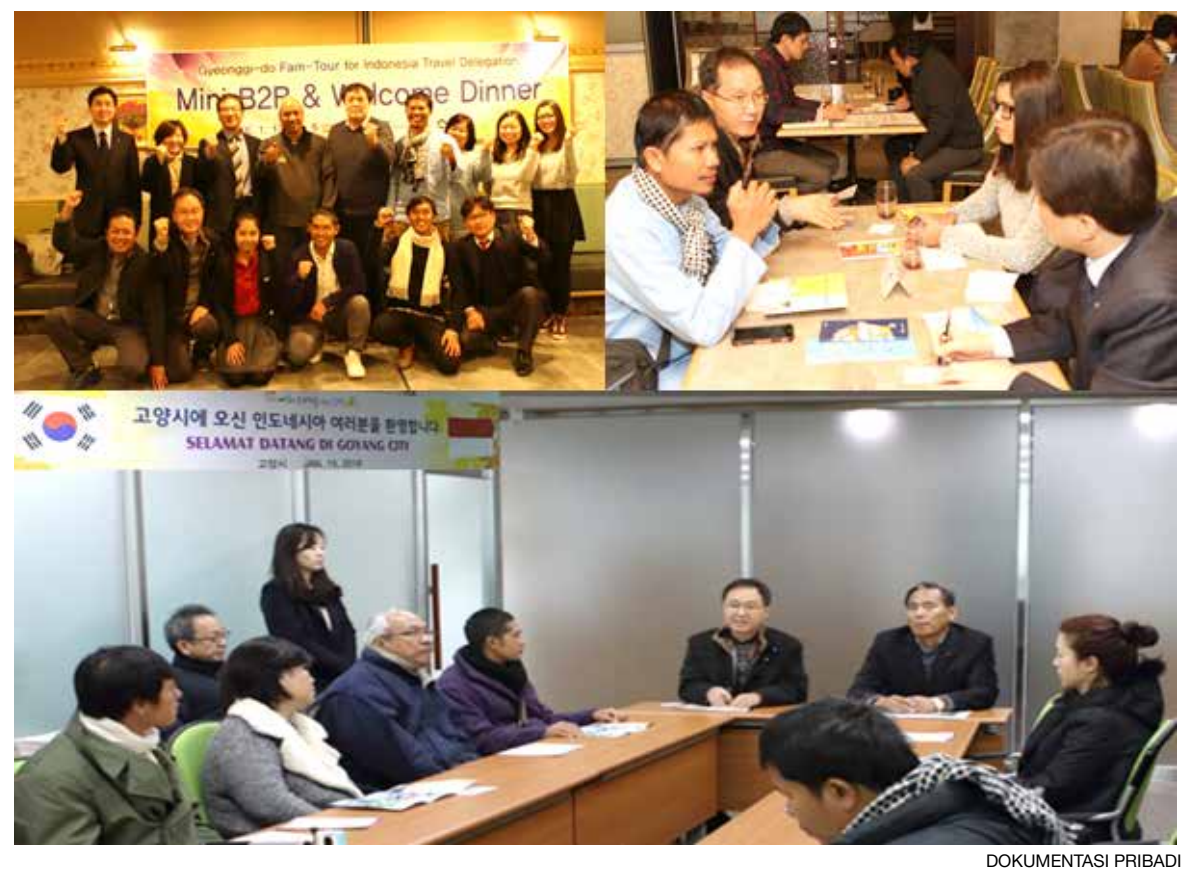

Gambar 1. Gyeonggi Fam Tour dan BtoB yang dilakukan di Kota Suwon dan Kota Goyang, Provinsi Gyeonggi pada tanggal 12-15 Januari 2016

produk-produk pariwisata di Provinsi Gyeonggi.

Metode penelitian yang digunakan secara keseluruhan merupakan penelitian deskriptif kualitati, meski begitu untuk mendukung penelitian dilengkapi data kuantitatif melalui penyebaran kuesioner. Lokasi penelitian ditetapkan di dua negara yaitu Korea (Provinsi Gyeonggi) dan Indonesia (DKI Jakarta dan Provinsi Bali). Teknik pengambilan dalam penelitian ini adalah purposive sampling yang berdasarkan suatu pertimbangan dimana yang diwawancarai adalah orang yang ahli dalam bidang yang diteliti oleh peneliti, maka sebagai informan, 14 orang dipilih, yakni delapan informan dari Korea, enam informan dari Indonesia seperti PNS, pegawai lembaga pariwisata atau agen-agen perjalanan wisata. (Lihat Gambar 1)

Metode survei dilakukan pada pertemuan acara promosi pariwisata Gyeonggi dan konsultasi Business to Business pada tanggal 13-15 Agustus 2015 di Jakarta dan pada tanggal 29-30 Juni 2016 di Bali, para peserta agen perjalanan wisata dimintai mengisi kuesioner sebagai responden pelaku pariwisata. Penelitian ini mengambil 80 kuesioner yang terdiri dari 49 agen perjalanan wisata di Bali dan 31 agen perjalanan wisata di Jakarta. Lokasi penelitian dapat dilihat pada Gambar 2 dan 3 sebagai berkut: 


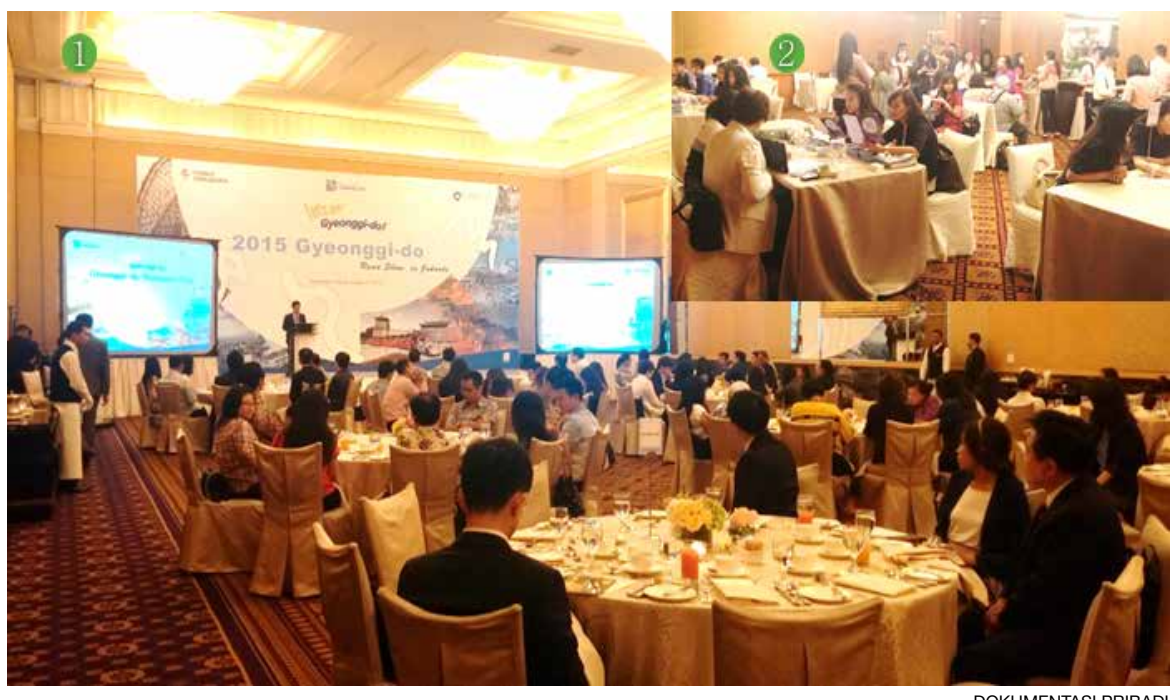

Gambar 2. Gambar 1 adalah acara promosi pariwisata Gyeonggi, Gambar 2 adalah Konsultasi $B$ to $B$ yang dilakukan di Hotel Mulia di DKI Jakarta, Indonesia pada pada tanggal 13-15 Agustus 2015.

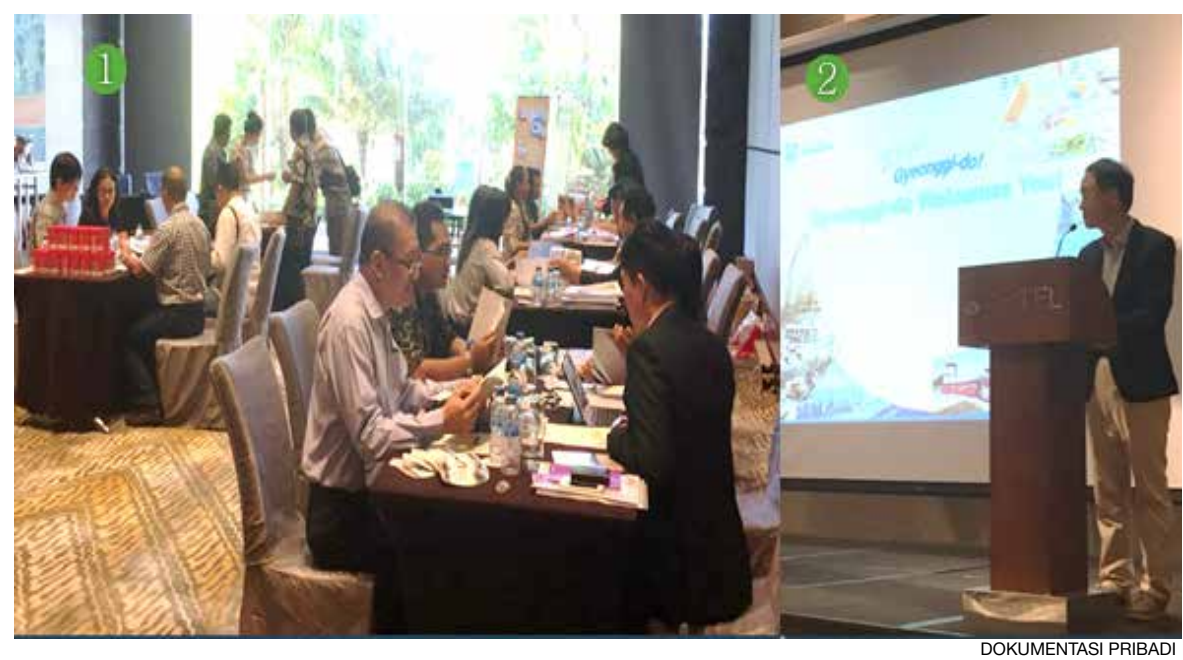

Gambar 3. Gambar 1 adalah Konsultasi BtoB, Gambar 2 adalah acara promosi pariwisata Gyeonggi yang dilakukan di Hotel Sofitel Nusadua, Bali pada tanggal 29-30 Juni 2016

\section{Persepsi terhadap Korea dan Gyeonggi}

Berdasarkan hasil penelitian, dalam jumlah 80 responden yang 31 orang berasal dari Jakarta dan 49 orang dari Bali, sebanyak 63 orang $(78,8 \%)$ pernah mendengar atau melihat produk wisata Korea. Apabila dilihat dari sisi daerah, orang berasal dari Jakarta $(22,6 \%)$ yang belum mengetahui terhadap Korea hampir sama dengan orang Bali(20,4\%) (Lihat Tabel 1). 
Tabel 1 Kesempatan Mendengar/Melihat Produk Wisata Korea

\begin{tabular}{ccccc}
\hline No & Pernah dengar/lihat & Jakarta & Bali & Total \\
\hline 1 & Pernah & $24(77,4 \%)$ & $39(79,6 \%)$ & $63(78,8 \%)$ \\
2 & Belum & $7(22,6 \%)$ & $10(20,4 \%)$ & $17(21,3 \%)$ \\
\hline Total & & $31(100 \%)$ & $49(100 \%)$ & $80(100 \%)$ \\
\hline
\end{tabular}

Sumber: Hasil Penelitian 2016

Sedangkan sebelum mengikuti acara promosi pariwisata Provinsi Gyeonggi yang diadakan di Indoensia, hanya 30\% responden agen perjalanan wisata pernah memiliki informasi terkait pariwisata Provinsi Gyeonggi, apabila dilihat dari jenis kelamin responden, laki-laki (33,3\%) lebih banyak yang sudah mengetahui Provinsi Gyeonggi daripada wanita $(26,3 \%)$ (Lihat Tabel 2).

Tabel 2 Kesempatan Memiliki Informasi terkait Provinsi Gyeonggi

\begin{tabular}{ccccc}
\hline No & Pengalaman & Laki-laki & \multicolumn{1}{c}{ Wanita } & Total \\
\hline 1 & Pernah & $14(33,3 \%)$ & $10(26,3 \%)$ & $24(30,0 \%)$ \\
2 & Belum & $28(66,7 \%)$ & $28(73,7 \%)$ & $56(70,0 \%)$ \\
\hline & Total & $42(100 \%)$ & $38(100 \%)$ & $80(100 \%)$ \\
\hline
\end{tabular}

Sumber: Hasil Penelitian 2016

Adapun hal yang menarik bahwa setelah acara promosi pariwisata Gyeonggi, 96,3\% responden agen perjalanan wisata menjawab bahwa ingin mengunjungi daya tarik wisata di Gyeonggi atau akan rekomendasikan produk wisata Gyeonggi pada tamunya, hasil lainya juga hampir sama terlihat terlepas dari daerah atau jenis kelamin (Tabel 3). Oleh karena itu, dapat dikatakan bahwa sebab utama yang dikarenakan rendahnya persepsi terhadap Gyeonggi adalah kurangnya pemasaran dan promosi.

Tabel 3 Minat mengunjungi tempat wisata di Gyeonggi setelah acara promosi

\begin{tabular}{ccrcrrl}
\hline \multirow{2}{*}{ No } & \multirow{2}{*}{ Keinginan } & \multicolumn{2}{c}{ Daerah } & \multicolumn{2}{c}{ Kelamin } & \multirow{2}{*}{ Total } \\
\cline { 3 - 6 } & mengunjungi & Jakarta & \multicolumn{1}{c}{ Bali } & \multicolumn{1}{c}{ Laki-laki } & Wanita & \\
\hline 1 & Mau & $30(96,8 \%)$ & $47(95,9 \%)$ & $41(97,6 \%)$ & $36(94,7 \%)$ & $77(96,3 \%)$ \\
2 & Tidak & $1(3,2 \%)$ & $2(4,1 \%)$ & $1(2,4 \%)$ & $2(5,3 \%)$ & $3(3,8 \%)$ \\
\hline & Total & $31(100 \%)$ & $49(100 \%)$ & $42(100 \%)$ & $38(100 \%)$ & $80(100 \%)$ \\
\hline
\end{tabular}

Sumber: Hasil Penelitian 2016

Berdasarkan hasil penelitian, kebanyakan wisatawan Indonesia memilih menggunakan paket wisata, sedangkan 52,5\% responden ingin mengunjungi Korea dengan cara wisata pribadi di masa yang akan datang. Dilihat dari sisi atribut agama, umat Hindu suka cara paket wisata (22 orang, 61,1\%), sedangkan umat Islam menyukai wisata pribadi (19 orang, 61,3\%). Hal ini dapat dilihat pada Tabel 4 . 
Tabel 4 Jenis wisata yang diminati wisatawan

\begin{tabular}{|c|c|c|c|c|c|}
\hline \multirow{2}{*}{\multicolumn{2}{|c|}{ No }} & \multicolumn{3}{|c|}{ Agama } & \multirow{2}{*}{ Total } \\
\hline & & Hindu & Islam & lain & \\
\hline 1 & Paket wisata & $22(61,1 \%)$ & $12(38,7 \%)$ & $4(30,8 \%)$ & $38(47,5 \%)$ \\
\hline 2 & Wisata pribadi & $14(38,9 \%)$ & $19(61,3 \%)$ & $9(69,2 \%)$ & $42(52,5 \%)$ \\
\hline & Total & $36(100 \%)$ & 31 (100\%) & $13(100 \%)$ & $80(100 \%)$ \\
\hline
\end{tabular}

Sumber: Hasil Penelitian 2016

Daya tarik wisata Provinsi Gyeonggi yang menarik bagi wisatawan Indonesia antara lain: DMZ (DeMilitarized Zone, 38,2\%) yang merupakan bukti otentik sejarah dari kisah kelam perang Korea yang sekaligus melambangkan perdamaian, English Village (31,6\%) yang memiliki luas sekitar 28 hektar, 49 gedung bernuansa barat dan disana wisatawan dapat belajar bahasa Inggris serta kebudayaan Korea, Everland (30,3\%) yang merupakan salah satu di antara 4 theme park yang terbesar di seluruh dunia, Benteng Hwaseong (23,7\%) yang telah mendapat pengakuan sebagai Warisan Budaya Dunia UNESCO dengan menikmati nuansa kerajaan Korea zaman dahulu (Lihat Tabel 5).

Selanjutnya melihat jenis pariwisata, wisata budaya (52,5\%), special interest tour $(36,3 \%)$, wisata edukasi, wisata industri $(33,8 \%)$, meditasi (20\%), medis (15\%) juga menarik minat orang Indonesia (Lihat Tabel 6). Hasil data tersebut menunjukan bahwa permintaan wisatawan Indonesia telah bergeser, wisatawan lebih memilih budaya, ilmu pengetahuan dan kecanggihan teknologi serta wisata berbasis edukasi daripada sekedar mengunjungi pantai dan bermain pasir (natural resources).

Tabel 5 Daya tarik wisata di Gyeonggi yang ingin dikunjungi

\begin{tabular}{lllll}
\hline \multirow{2}{*}{ No } & $\begin{array}{l}\text { Daya tarik wisata } \\
\text { yang ingin dikunjungi }\end{array}$ & \multicolumn{2}{c}{ Daerah } & \multirow{2}{*}{ Total } \\
\cline { 2 - 4 } 1 & DMZ, Imjingak & $13(44,8 \%)$ & $16(34,0 \%)$ & $29(38,2 \%)$ \\
2 & English Village & $9(31,0 \%)$ & $15(31,9 \%)$ & $24(31,6 \%)$ \\
3 & Everland & $9(31,0 \%)$ & $14(29,8 \%)$ & $23(30,3 \%)$ \\
4 & Warisan Budaya Dunia & $6(20,7 \%)$ & $12(25,5 \%)$ & $18(23,7 \%)$ \\
5 & Pulau Jara / Gapyeong & $6(20,7 \%)$ & $9(19,1 \%)$ & $15(19,7 \%)$ \\
6 & City of Crafts and Folk Art & $5(17,2 \%)$ & $7(14,9 \%)$ & $12(15,8 \%)$ \\
7 & Kintex, Onemount & $5(17,2 \%)$ & $6(12,8 \%)$ & $11(14,5 \%)$ \\
8 & Petite Franc, Swiss Village & $3(10,3 \%)$ & $6(12,8 \%)$ & $9(11,8 \%)$ \\
\hline \multicolumn{2}{c}{ Total } & $29(100 \%)$ & $47(100 \%)$ & $76(100 \%)$ \\
\hline
\end{tabular}

Sumber: Hasil Penelitian 2016 
Tabel 6 Jenis wisata yang paling sesuai bagi wisatawan Indonesia

\begin{tabular}{|c|c|c|c|c|}
\hline \multirow{2}{*}{ No } & \multirow{2}{*}{ Jenis wisata } & \multicolumn{2}{|c|}{ Kelamin } & \multirow{2}{*}{ Total } \\
\hline & & Laki-laki & Wanita & \\
\hline 1 & Wisata Budaya & $21(50,0 \%)$ & $21(55,3 \%)$ & $42(52,5 \%)$ \\
\hline 2 & Special Interest Tour & $20(47,6 \%)$ & $9(23,7 \%)$ & $29^{`}(36,3 \%)$ \\
\hline 3 & Wisata Edukasi & $14(33,3 \%)$ & $13(34,2 \%)$ & $27(33,8 \%)$ \\
\hline 4 & Wisata Industri & $9(21,4 \%)$ & $18(47,4 \%)$ & $27(33,8 \%)$ \\
\hline 5 & Wisata Sejarah & $13(31,0 \%)$ & $11(28,9 \%)$ & $24(30,0 \%)$ \\
\hline 6 & Meditasi, templestay & $10(23,8 \%)$ & $6(15,8 \%)$ & $16(20,0 \%)$ \\
\hline 7 & Wisata Medis & $8(19,0 \%)$ & $4(10,5 \%)$ & $12(15,0 \%)$ \\
\hline 8 & Festival Tour & $1(2,4 \%)$ & $8(21,1 \%)$ & $9(11,3 \%)$ \\
\hline 9 & Wisata berhijau & $3(7,1 \%)$ & $5(13,2 \%)$ & $8(10,0 \%)$ \\
\hline 10 & Wisata MICE & $3(7,1 \%)$ & $3(7,9 \%)$ & $6(7,5 \%)$ \\
\hline & Total & $42(100 \%)$ & $38(100 \%)$ & $80(100 \%)$ \\
\hline
\end{tabular}

Sumber: Hasil Penelitian 2016

\section{Strategi Pemasaran Pariwisata Gyeonggi}

\subsection{Analisis SWOT}

Berdasarkan survei dan wawancara yang dilakukan dengan para pemangku kepentingan (stakeholders) di Provinsi Gyeonggi dan Indonesia (Jakarta dan Bali), dapat ditunjukkan hasil identifikasi yang menarik terkait dengan faktor eksternal maupun internal. Adapun hasil analisis faktor kekuatan, kelemahan, peluang dan ancaman yang terkait dengan kebijakan peningkatan wisatawan Indonesia ke Korea termasuk Provinsi Gyeonggi dapat dirumuskan seperti Tabel 7 .

\subsection{Segmentasi Pasar dan Penetapan Target Pasar Pariwisata}

Melihat dari preferensi wisatawan Indonesia, hasil segmentasi pasar serta target pasar Provinsi Gyeonggi dapat diklasifikasikan sebagai berikut.

\section{Produk Paket wisata termasuk Hallyu}

Saat ini cukup banyak wisatawan Indonesia mengunjungi Korea dan sebagian besar menggunakan paket perjalanan, maka dalam paket wisata gaya keluarga yang sedang dipromosikan dapat dicantumkan daya tarik wisata Provinsi Gyeonggi. Cara tersebut relatif mudah untuk menarik minat wisatawan dan dapat berhasil dalam waktu singkat walaupun keuntungannya tidak begitu besar. Aktivitas pengalaman budaya Korea oleh peserta Gyeonggi Fam Tour dapat dilihat pada Gambar 4.

Hal yang terkait Hallyu juga ditegaskan dalam wawancara dengan Shin Minju, pegawai Santa Tour Travel Agency, yang merupakan salah satu partisipan dalam acara konsultasi BtoB (Business to Business) pada Juni 2016 di Bali sebagai berikut: 
Tabel 7 Matriks SWOT Pariwisata Provinsi Gyeonggi

\begin{tabular}{|c|c|c|}
\hline & STRENGTHS (S) & WEAKNESSES (W) \\
\hline $\begin{array}{l}\text { Faktor-Faktor } \\
\text { Eksternal }\end{array}$ & $\begin{array}{l}<\text { Korea }> \\
\text { S1 Citra Korea } \\
\text { S2 Keadaan empat musim } \\
<\text { Gyeonggi> } \\
\text { S3 Lokasi Gyeonggi dekat bandara } \\
\quad \text { Incheon. } \\
\text { S4 Tempat berbelanja yang besar } \\
\quad \text { dan digemari oleh orang asing } \\
\text { S5 Lokasi syuting yang popluer } \\
\text { S6 Daya tarik DMZ } \\
\text { S7 Daya tarik ilmu pengetahuan } \\
\quad \text { dan kecanggiihan teknologi } \\
\text { S8 Daya tarik temple stay }\end{array}$ & $\begin{array}{l}<\text { Korea }> \\
\text { W1 Harga murah dengan kualitas } \\
\quad \text { rendah yang tidak baik } \\
\text { W2 Kesulitan Tourist Visa } \\
\text { W3 Perbelanjaan wajib } \\
\text { W4 Harga Pesawat relatif mahal } \\
<\text { Gyeonggi> } \\
\text { W5 Kurangnya promosi } \\
\text { W6 Persepsi wisatawan tentang } \\
\quad \text { Gyeonggi } \\
\text { W7 Kurangnya tempat wisata di } \\
\text { malam hari }\end{array}$ \\
\hline OPPORTUNITIES $(O)$ & STRA & \\
\hline $\begin{array}{l}\text { Korea }> \\
\text { O1 Perkembangan Ekonomi } \\
\quad \text { Indonesia } \\
\text { O2 Trend pariwisata } \\
\text { O3 Investasi pKorea di Indonesia } \\
\text { O4 pertukaran budaya, } \\
<\text { Gyeonggi> } \\
\text { O6 Peningkatan jumlah kunjungan } \\
\quad \text { di Korea } \\
\text { O7 kerjasama pemerintah daerah } \\
\text { antara dua negara }\end{array}$ & $\begin{array}{l}\text { 1) Mengembangkan pariwisata } \\
\text { musim dingin, semi, dan gugur } \\
\text { 2) Mengemas produk wisata } \\
\text { budaya Korea lebih atraktif } \\
\text { 3) Menciptakan produk wisata } \\
\text { kelompok insentif perusahaan } \\
\text { 4) Mempromosikan pariwisata } \\
\text { alternatif melalui segmentasi } \\
\text { dan menentukan target pasar }\end{array}$ & $\begin{array}{l}\text { 1) Meningkatkan kerjasama } \\
\text { pemerintah daerah antara } \\
\text { kedua negara } \\
\text { 2) Mempromosikan pariwisata } \\
\text { alternatif yang berkualitas } \\
\text { 3) Menawarkan produk wisata } \\
\text { dengan harganya normal dan } \\
\text { wajar } \\
\text { 4) Mendorong niat kunjungan } \\
\text { berulang } \\
\text { 5) Meningkatkan jumlah } \\
\text { pemandu wisata berbahasa } \\
\text { Indonesia }\end{array}$ \\
\hline THREATS (T) & STRATEGI $S T$ & DINAIEUIVI \\
\hline $\begin{array}{l}<\text { Korea }> \\
\text { T1 Kebijakan pariwisata nega- } \\
\text { ra-negara tetangga } \\
\text { T2 Kebijakan Bebas Tourist Visa } \\
\text { Jepang } \\
\mathrm{T} 3 \text { Kunjungan ulang rendah } \\
<\text { Gyeonggi> } \\
\mathrm{T} 4 \text { Kebijakan promosi pemerintah } \\
\text { daerah lain } \\
\mathrm{T} 5 \text { Wisata berbelanja terpusat di } \\
\text { ibu Kota Seoul }\end{array}$ & $\begin{array}{l}\text { 1) Mempromosikan pariwisata } \\
\text { industri berteknologi canggih } \\
\text { 2) Memfokuskan wanita usia } \\
\text { setengah baya untuk wisata } \\
\text { medis } \\
\text { 3) Mempromosikan pariwisata } \\
\text { pertahanan DMZ } \\
\text { 4) Menciptakan produk wisata } \\
\text { yang berbeda dengan wisata } \\
\text { Seoul }\end{array}$ & $\begin{array}{l}\text { 1) Memformulasikan Kebijakan } \\
\text { Bebas Tourist Visa } \\
\text { 2) Tersedianya sarana dan prasa- } \\
\text { rana sesuai persepsi wisatawan } \\
\text { 3) Membangun database pari- } \\
\text { wisata } \\
\text { 4) Membangun lembaga promosi } \\
\text { pariwisata } \\
\text { 5) Menciptakan Konfigurasi } \\
\text { produk wisata } \\
\text { 6) Komersialisasi wisata malam di } \\
\text { Kota Suwon, Goyang, Ansan, dll }\end{array}$ \\
\hline
\end{tabular}

Sumber: Hasil Penelitian tahun 2016

"Wisatawan Indonesia juga menyukai budaya Korea, maka baru-baru ini pertanyaan calon wisatawan Indonesia untuk kunjungan Korea mengalami kenaikan berkat drama Korea "Descendant of Sun", sehingga hal ini berkontribusi pada peningkatan wisatawan Indonesia ke Korea” (Wawancara 12 Juli 2016)

Dengan kata lain, daya tarik wisata tempat syuting di Provinsi Gyeonggi yang dicantumkan dalam paket wisata Korea dapat dipromosikan pada target pasar Indonesia, yaitu kepada calon wisatawan umum di Jawa dan Bali. 


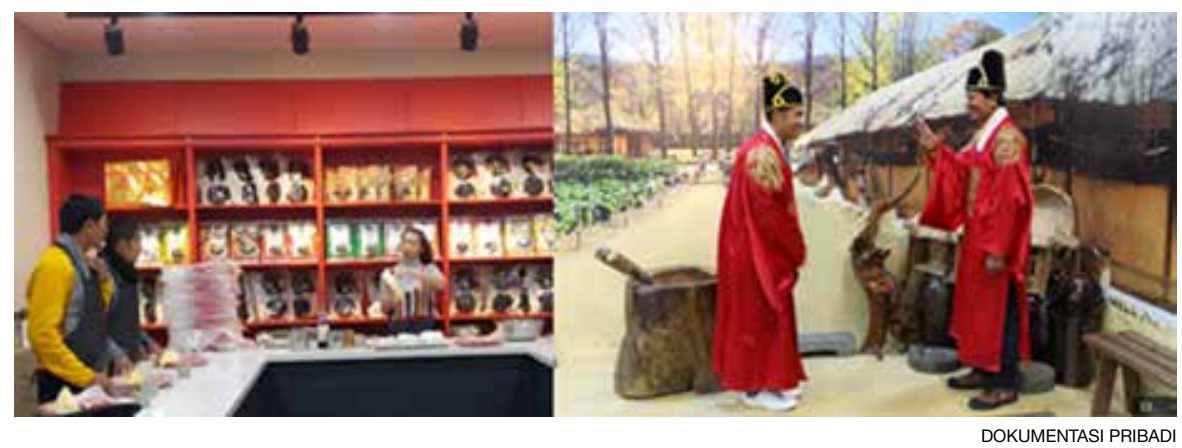

Gambar 4 Tim kunjungan Indonesia yang sedang mengalami budaya Korea.

\section{Produk Wisata Meditasi}

Ritual keagamaan masyarakat Indonesia memberikan ciri khas tersendiri pada ketertarikan pariwisata spiritual ataupun meditasi di Temple Stay, Korea. Terutama dalam kalangan agama Hindu di Indonesia dapat dilihat bahwa ritual upacara pemujaan memiliki kesamaan yang cukup jelas dengan kebudayaan agama Buddha di Korea. Sebuah Temple (kuil Buddha) tetap menjadi pengalaman baru bagi wisatawan dan belajar secara langsung tentang budaya Buddhis Korea. Program Temple Stay ini dikelola di 20 kuil yang ada di Gyeonggi, hampir semuanya terletak di gunung yang jauh dari kota-kota, sehingga semua pengunjung dapat menikmati suasana tenang.

Secara praktis, melihat preferensi produk wisata meditasi, rasio rata-rata dalam jumlah 80 responden adalah 7,1\%, sedangkan umat Hindu (11,5\%) lebih gemar dibandingkan umat Islam (1,8\%). Dengan demikian, dapat dikatakan bahwa produk wisata meditasi di Provinsi Gyeonggi berpontensi untuk dikembangkan dan dipromosikan pada target pasar umat Hindu.

\section{Produk Wisata Industri}

Wisata Industri yang bakal menjadi daya tarik wisata saat ini di Provinsi Gyeonggi adalah 19 perusahaan, delapan di antaranya adalah perusahaan makanan, 3 industri perfilman, 3 industri mobil, 2 perusahaan elektrik, 1 perusahaan kosmetik, dan lain-lain.

Sandijaya, wartawan Radar Bali (Jawa Pos Group) yang mengikuti Gyeonggi Fam Tour pada Januari 2016, memberikan keterangan tentang wisata industri sebagai berikut:

\footnotetext{
"Saya mengunjungi daya tarik wisata Provinsi Gyeonggi antara lain tempat yang paling menarik bagi mahasiswa atau remaja merupakan Samsung Museum Inovasi di Kota Suwon. Pengunjung dapat merasakan dan melihat sejarah, mempesona, dan inovasi industri elektronik termasuk Samsung Electronics terbesar di Korea. Itu pengalaman luar biasa” (Lihat Gambar 5, Wawancara 29 Januari 2016).
} 


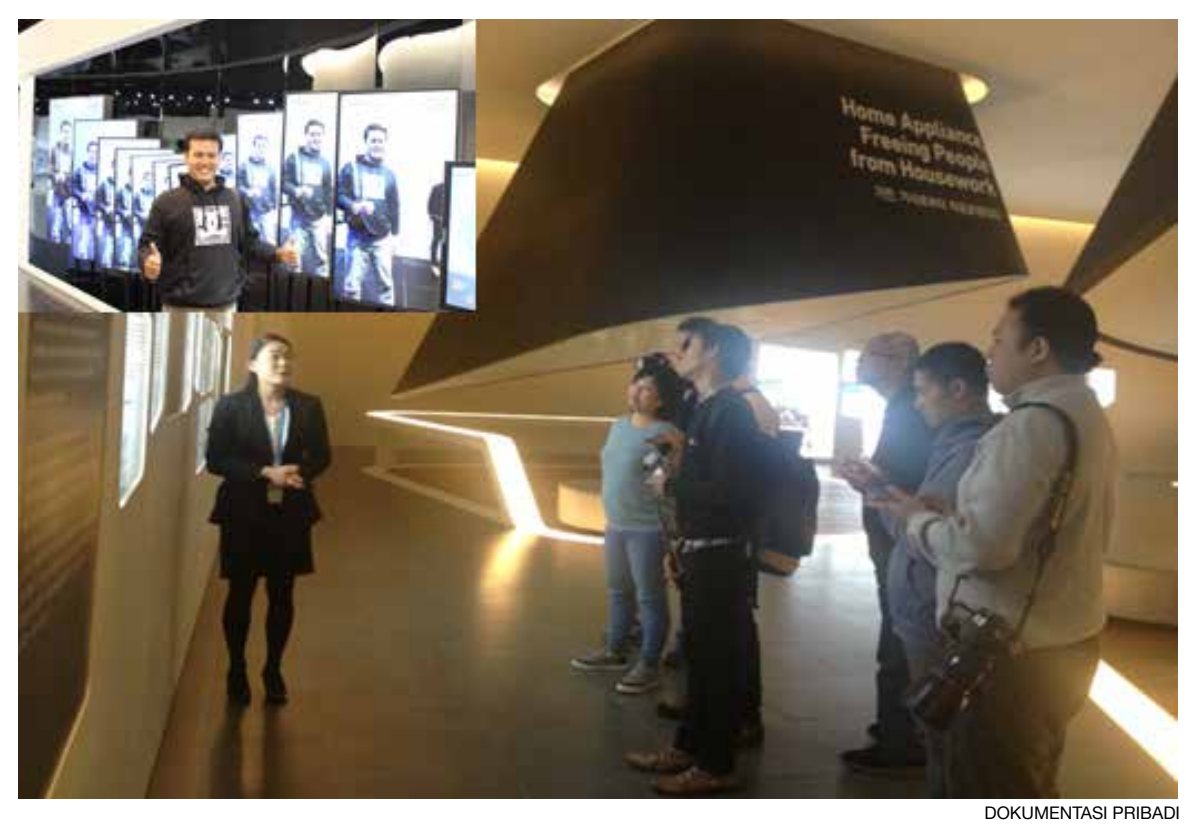

Gambar 5 Peserta Fam Tour sedang berkunjung di Samsung Museum Inovasi.

Berdasarkan pernyataan tersebut, berarti bahwa produk wisata industri di Provinsi Gyeonggi dipromosikan pada target pasar remaja seperti siswa dan mahasiswa.

\section{Produk Wisata Edukasi}

Bagi wisatawan yang ingin berkunjung ke Korea, khususnya Provinsi Gyeonggi tetapi tujuanya tidak hanya berwisata melainkan juga belajar atau yang bersifat edukatif, salah satu yang dapat menjadi pilihan adalah Gyeonggi English Village. Sampai saat ini, tercatat sejumlah 4.417 wisatawan asing telah mengikuti English program di Gyeonggi English Village sambil menikmati budaya Korea.

Adapun wisata edukasi diproyeksikan dalam hasil wawancara dengan Song Geumhee, direktur e-Korea Tour Travel Agency di Gyeonggi yang berpartisipasi dalam acara konsultasi BtoB (Business to Business) pada Agustus 2015 di Jakarta dan Juni 2016 di Bali sebagai berikut:

"Mempertimbangkan bahwa Indonesia adalah salah satu negara yang antusiasme pendidikannya sangat tinggi dan angka mahasiswa meningkat drastis, semakin banyak mahasiswa berharap belajar di luar negeri baik studi jangka pendek maupun studi jangka panjang, maka produk wisata pendidikan sangat menarik pada siswa" (Wawancara 5 Juli 2016).

Sebagai produk wisata pendidikan, target ditujukan pada International 


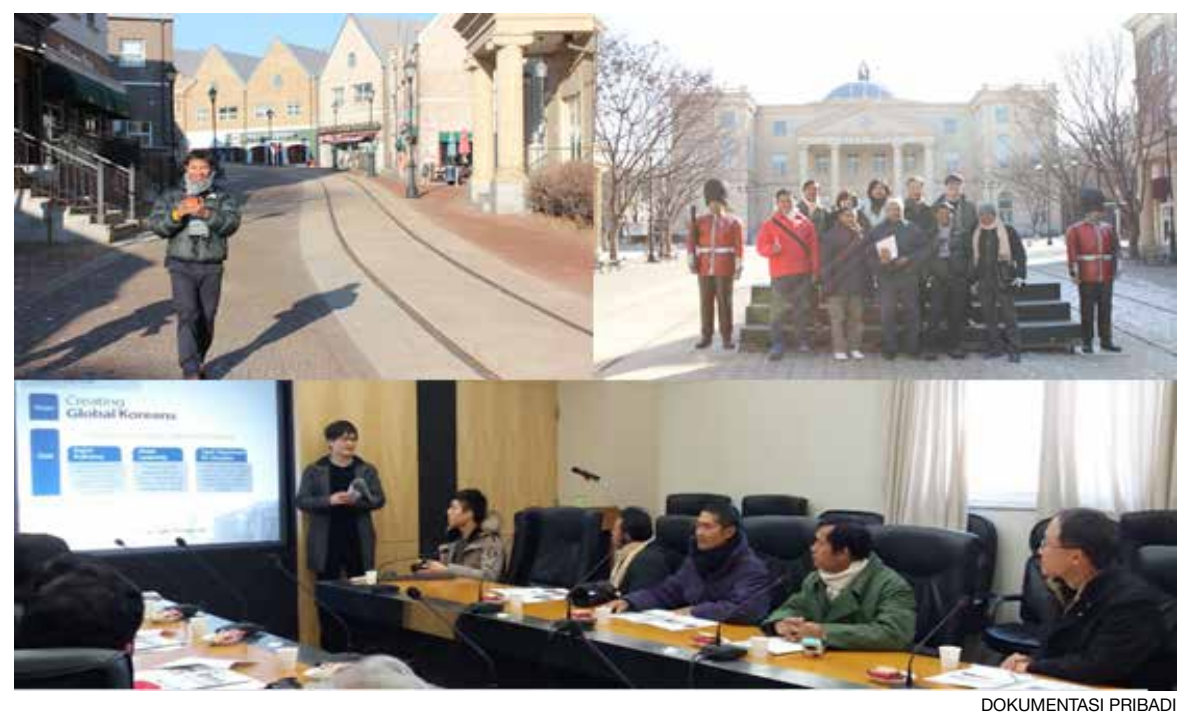

Gambar 6 Peserta Fam Tour sedang berkunjung di English Village

School atau sekolah swasta yang kebanyakan siswa adalah kelas menengah dan atas. Artinya, International School yang ada di Indonesia diharapkan melakukan kerjasama dengan Gyeonggi English Village untuk mendapatkan pengetahuan budaya Korea dan budaya Western. Salah satu aktivitas tim kunjungan Indonesia pada bulan Januari tahun 2016 tampak pada Gambar 6.

\section{Produk Wisata Kesehatan}

Menurut data statistik (Korea Health Industry Development Institute, 2013), pada tahun 2012, jumlah pasien asing di Korea mencapai 155.625. Jumlah tersebut mengalami peningkatan 27,2\% dibandingkan dengan tahun 2011, maka terjadi peningkatan 31.823 orang per tahun selama tiga tahun (CAGR 37,3\%). Sedangkan pasien dari Indonesia mengalami peningkatan dari rata-rata $53,9 \%$ per tahun selama tiga tahun menjadi 667 orang pada tahun 2012.

Pada tahun 2013, sekitar 600 ribu orang Indonesia pergi berobat ke luar negeri. Jumlah ini mengindikasikan bahwa terdapat banyak orang Indonesia yang bepergian ke luar negeri untuk mendapat perawatan kesehatan sekaligus liburan. Oleh karena itu, dapat dinyatakan bahwa wisata medis perlu dipromosikan pada golongan wanita muda dan wanita setengah baya yang berasal dari kelas ekonomi tingkat atas, atau wisatawan bisnis yang masa kunjungannya agak panjang.

\section{Produk Wisata Khusus}

Kekuatan atau pendorong utama dalam pengembangan destinasi wisata Provinsi Gyeonggi adalah produk wisata pertahanan seperti DMZ yang 
satu-satunya hanya ada (the only one) di Korea dan di seluruh dunia. Lee Hanok, pegawai LNT Tour Travel Agency di Gyeonggi yang berpartisipasi dalam acara konsultasi BtoB (Business to Business) pada Juni 2016 di Bali, memberikan pernyataannya terhadap DMZ sebagai berikut:

\begin{abstract}
"Tempat ini hanya bisa dijangkau melalui perjalanan khusus yang sebelumnya telah disetujui oleh dinas pengelola di sini. Wisata pertahanan ini sangat menarik bagi wisatawan minat khusus karena uniknya bentuk perbatasan antara Korea Selatan dan Korea Utara yang terbentuk sejak berakhirnya Perang Korea pada tahun 1953 dan merupakan perbatasan negara yang paling termiliterisasi di dunia, membentang sepanjang $250 \mathrm{~km}$ dengan lebar $4 \mathrm{~km}$. Apalagi sebelumnya siapa pun tidak boleh masuk selama sekitar 70 tahun" (Wawancara 7 Juli 2016).
\end{abstract}

Oleh karena itu, dapat dikatakan bahwa wisata pertahanan (DMZ, Imjingak, Terowongan rahasia, Panmunjom) yang hanya dapat ditemukan di Provinsi Gyeonggi layak direkomendasikan sebagai wisata minat khusus kepada calon wisatawan Indonesia.

\title{
Konfigurasi Produk Wisata
}

Kekuatan utama di pariwisata Provinsi Gyeonggi dianggap sebagai daya tarik wisata alternatif yang beraneka ragam seperti DMZ, Temple Stay dan tempat-tempat wisata edukatif yang menyajikan kecanggihan teknologi seperti Samsung Smartphone. Kekuatan lainnya adalah lokasi Gyeonggi dekat dengan bandara Incheon yang berstandar kelas dunia dalam sisi pelayanan dan aksesbilitas yang baik di Korea karena ditetapkan sebagai lokasi penyuntingan film internasional maupun domestik, dan terdapat beberapa premium outlet maupun bebas pajak untuk wisata belanja.

Lebih lanjut, Korea bersama Cina dan Jepang, memiliki musim semi, musim gugur dan musim dingin yang berbeda dengan musim di Indonesia beriklim tropis. Jika produk wisata yang dipromosikan di Indonesia mencantumkan konfigurasi daya tarik wisata yang ada di negara tetangga yaitu, Cina dan Jepang, maka produk akan memiliki nilai respon yang tinggi oleh wisatawan Indonesia. Sebagai contoh, konfigurasi produk Korea dan Cina, Korea dan Jepang, ataupun Korea, Jepang, dan Cina.

Belakangan ini pertumbuhan ekonomi Indonesia telah mendorong peningkatan taraf kelas ekonomi menengah ke atas, sehingga semakin banyak wisatawan Indonesia yang ingin berwisata ke luar negeri dengan produk wisata yang berkualitasi tinggi. Dengan demikian, produk wisata yang digabungkan dua negara dalam satu produk wisata dapat dipromosikan pada target pasar Indonesia, yaitu kepada calon wisatawan kelas ekonomi menengah ke atas. 


\subsection{Positioning Pasar Pariwisata Geyonggi}

Berdasarkan hasil penelitian, positioning pariwisata Gyeonggi ditinjau ke dalam dua masa yaitu masa kini/sebelum positioning dan masa depan/ setelah positioning. Positioning pariwisata Gyeonggi masa kini terfokus pada mass tourism untuk meningkatkan jumlah kunjungan wisatawan asal Indonesia ke Gyeonggi melalui paket wisata. Permasalahannya, posisi pariwisata Gyeonggi saat ini menghadapi tantangan pada praktek dumping, yaitu harga tidak normal yang dijalankan oleh agen perjalanan wisata sebagai akibat dari persaingan usaha. Praktek ini bersifat umum karena hampir ditemukan produk yang sama dimanapun, baik di Jakarta maupun Bali. Calon wisatawan ditawarkan harga paket wisata yang tidak normal sebagai dumping, maka dari itu kualitasnya dianggap rendah. Positioning pariwisata Gyeonggi dapat dilihat pada Gambar 7:
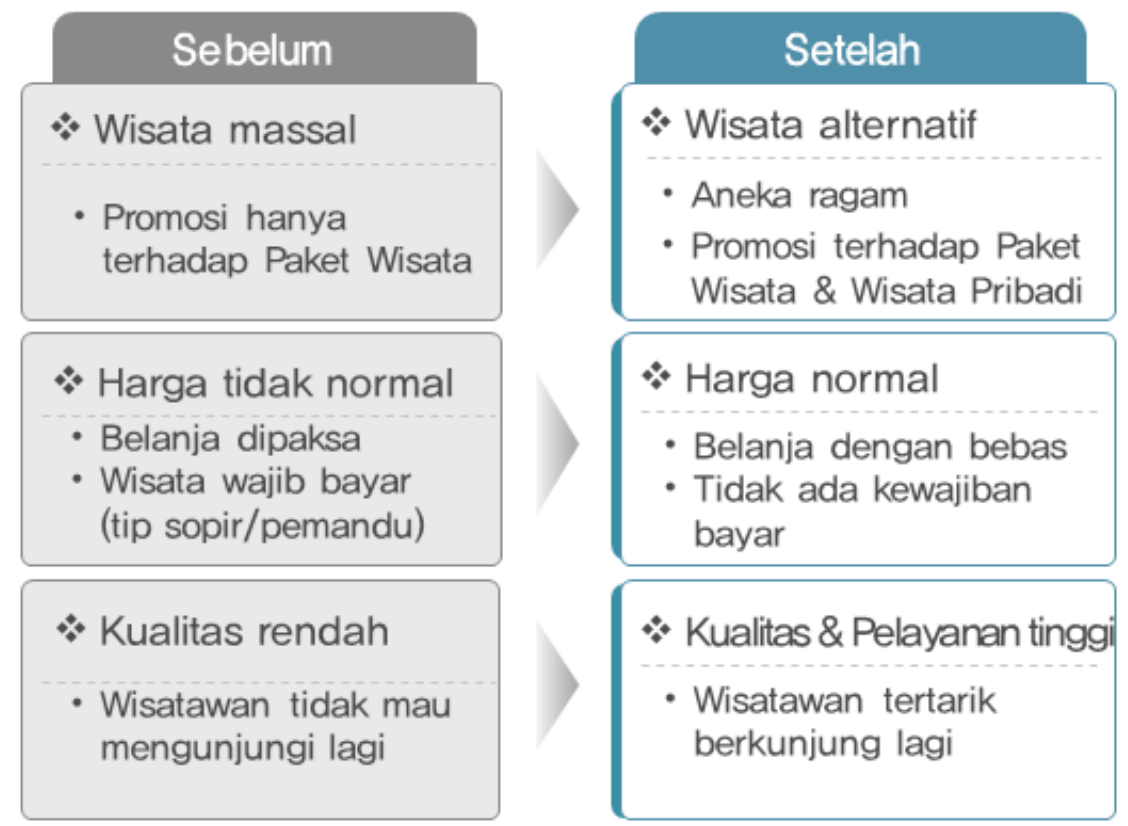

Gambar 7. Positioning pariwisata Gyeonggi (Sumber: Hasil Penelitian, 2016)

Mengantisipasi kondisi yang demikian, pariwisata Gyeonggi di masa depan diharapkan memposisikan wisata alternatif yang menawarkan produk wisata yang beraneka ragam untuk dua tipologi wisatawan yaitu paket wisata dan wisata pribadi. Perubahan citira Gyeonggi tersebut diharapkan memengaruhi pengambilan keputusan calon wisatawan Indonesia dalam memilih berwisata ke Gyeonggi seperti berkut: Pertama, wisatawan Indonesia dapat menggunakan wisata alternatif aneka ragam di Gyeonggi yang telah disediakan oleh agen-agern perjalanan wisata. Kedua, 
wisatwawan individual Indonesia merencanakan perjalanannya sendiri ke Provinsi Gyeonggi atau wisata pribadi.

Dengan menerapkan positioning terhadap Gyeonggi sebagai destinasi wisata yang menawarkan aneka ragam produk berkualitas tinggi, praktik dumping saat ini, yang berupa ketidaknormalan harga, dapat diatasi. Dengan kata lain, permasalahan struktural berupa paket wisata sejenis yang ditawarkan di Indonesia dapat diperbaiki dengan cara membentuk citra produk wisata Gyeonggi yang berkualitas dan menyuguhkan pengalaman serta pengetahuan yang baru dan unik.

Dengan demikian memaksimalkan manfaat dari produk-produk pariwisata alternarif atau wisata tematik di Gyeonggi sebagai pengganti "biayanya tidak normal dan kualitasnya juga rendah" sehingga memberikan kesan yang baik di benak wisatawan Indonesia untuk mengambil keputusan dalam memilih produk pariwisata atau daya tarik wisata yang ada di Gyeonggi.

\section{Strategi Promosi Pariwisata Geyonggi}

Strategi promosi pariwisata Gyeonggi dapat diatur dalam tiga aspek sebagai berikut.

Pertama, agen perjalanan wisata Provinsi Gyeonggi secara aktif melakukan pemasaran di Indonesia. Aktivitas pemasaran diharapkan sesuai dengan produk dan target pasar yang berbeda-beda di Indonesia. Dengan demikian, dibangun hubungan kepercayaan sehingga BtoB, Fam Tour yang diselenggarakan oleh Provinsi Gyeonggi dapat menjadi jembatan bagi agen perjalanan wisata antara kedua negara. Selanjutnya, agen perjalanan wisata di kedua negara bersama-sama menciptakan produk wisata yang disesuaikan dengan preferensi wisatawan Indonesia, akhirnya bersamasama mempromosikan produk pariwisata yang mencerminkan kebutuhan atau keinginan wisatawan Indonesia guna ekspansi kualitas kepuasan wisatawan Indonesia.

Kedua, strategi pemasaran melalui Online adalah cara promosi yang paling umum dan mudah karena pengguna smartphone semakin berkembang jumlahnya, termasuk di Indonesia. Cara lain adalah menghimpun sekelompok wartawan yang meliput 'Pariwisata Gyeonggi'. Wartawan yang dimaksud tidak hanya terbatas pada wartawan professional namun jurnalis-jurnalis yang berasal dari sekolah-sekolah di Indonesia juga patut dipertimbangkan. Jurnalis-jurnalis sekolah ini membantu menyediakan layanan yang dapat berfungsi untuk menyebarkan artikel yang tepat terkait dengan Pariwisata Gyeonggi dengan menggunakan Situs Jaringan Sosial (SNS, Social Networking Site) dan mendorong komunikasi dua arah antara pihak Provinssi Gyeonggi dan pihak wisatawan.

Ketiga, peningkatan persepsi terhadap Gyeonggi diharapkan mampu 
ditingkatkan dengan meningkatkan hubungan kerjasama dengan Kota/Kabupaten di Indonesia. Ada tiga pendekatan yang dilaksanakan untuk menjalin kerjasama dengan Pemerintah Daerah dalam menunjang keberhasilan sektor pariwisata di Provinsi Gyeonggi antara lain adalah sinergi kerjasama antara Pemerintah Daerah. Kemitraan ini dibangun untuk memperluas pertukaran antara kedua negara, dan pameran pariwisata yang diselenggarakan pemerintah daerah di Gyeonggi, di mana penyelengaraannya dilangsungkan di Indonesia. Kemudian kerjasama dengan lembaga pendidikan, yaitu membantu lembaga atau institusi pendidikan untuk saling bekerja sama antara Universitas di Gyeonggi dan di Indonesia. Lalu, kerjasama dengan pihak swasta. Sebagaimana diketahui Provinsi Gyeonggi memiliki tempat yang lengkap untuk film atau drama yang ditawarkan pada perusahaan atau industri perfilman di Indonesia untuk menampilkan daya tarik wisata seperti kuliner dan budaya Korea.

\section{Penutupan}

Fakta yang menarik selama penelitian untuk artikel ini adalah Provinsi Gyeonggi dan Indonesia memiliki kesamaan dalam fenomena kunjungan wisatawan. Potensi sumber daya pariwisata di Provinsi Gyeonggi beragam dan menarik. Namun, jumlah kunjungan wisatawan asing di Provinsi Gyeonggi belum signifikan dibandingkan dengan Ibu Kota Seoul atau Pulau Jeju. Demikian halnya di Indonesia, potensi daya tarik wisata yang dimiliki mencanangkan terutama keindahan alam dan budaya. Kendati demikian, wisatawan mancanegara yang berkunjung ke Indonesia relatif lebih sedikit dibandingkan dengan negara-negara tetangga. Jumlah wisatawan mancanegara ke Indonesia mencapai sekitar 9 juta orang pada tahun 2015, masih berada di bawah Malaysia (27 juta wisatawan), Thailand (24 juta wisatawan) dan Singapura (15 juta wisatawan). Berdasarkan data dan fakta tersebut maka peneliti berharap hasil penelitian artikel ini memberikan solusi konstruktif untuk pembangunan kepariwisataan Korea dan Indonesia di masa depan.

\section{Ucapan Terima Kasih}

Ucapan terima kasih sepenuh hati saya sampaikan pada pembimbing Prof. Darma Putra dan Dr. Syamsul Alam Paturusi, yang dengan keikhlasan hati telah membimbing saya menyeleaikan tesis ini. Selama dua tahun sebagai mahasiswa asing di Prodi Magister Kajian Pariwisata Universitas Udayana, memberikan keberuntungan bagi saya karena bantuan temanteman Indonesia yang ramah, unik, dan terbuka. Begitu pula dosen-dosen dan staff prodi yang ramah dan terbuka. Tak ada kata yang lebih indah untuk saya ucapkan selain terima kasih kepada dosen pembimbing, staff dan teman-teman di Program Studi Magister Kajian Pariwisata. 


\section{Daftar Pustaka}

Fandeli C. 2002. Perencanaan Kepariwisataan Alam. Fakultas Kehutanan, Universitas Gadjah Mada.Yogyakarta.

Ha Kyunghee. 2008. Inducing Strategy of Chinese Tourists; -Focusing on the HallyuKorean Wave-. Tourism Research. 26: 109-128

Han Huijoo and Lee Jaeseob. 2009. Exploratory Study on Muslim Malaysians visiting Korea and their tourism market. Tourism Management Research. 13(1): 121133 .

Kedutaan besar Republik Indonesia di Seoul. 2015. [diakses 20. Juni 2016]. http:// kbriseoul.kr/kbriseoul/ index.php/id/indokor

Kim Gicheol. 2015. A Study on the Strategy for Attracting Tourists of Sister Sities in China to Gyeonggi-Do. Studi dasar 2015-30. Gyeonggi Reseach Institute.

Kim Heungsik. 2009. Marketing Strategies Attracting Chinese Tourists to GyeonggiDo. Studi dasar 2009-2. Gyeonggi Reseach Institute.

Kim Heungsik. 2013. A Strategy for the Development of Mice Industry as New Engine of Growth in Gyeonggi-Do. Studi dasar 2013-40. Gyeonggi Reseach Institute.

Kim Jaewon. 2012. Tourists Characteristics of South-East Asian inbound market in Korea. Penelitian pariwisata Vol. 20. Institute Tourism Korea.

Korea Creative Content Agency. 2014. Indonesia Cultural code for overseas market expansion of the Korea Creative Contents. Korea Creative Content Agency

Korea Tourism Organization. 2015. [diakses 18. Januari 2016]. http:// www. visitkorea.or.kr

Korea Trade-Investment Promotion Agency. 2015. [diakses 15. Januari 2016] http:// www.kotra.or.kr/kh/main/ KHMIUIo1oM.html

Kotler dan Keller. 2009. Manajemen Pemasaran (Marketing Management), Edisi Ketiga Belas Jilid I. Jakarta : Erlangga.

Lee Sujin. 2014. Reseach on Developing Strategic Policies for Medical Tourism in Gyeonggi-Do. Studi dasar 2014-04. Gyeonggi Reseach Institute.

Pitana I Gde dan Diarta I Ketut Surya. 2009. Pengantar Ilmu Pariwisata. Yogyakarta: Penerbit Andi.

Provinsi Gyeonggi. 2015. Buku Tahunan StatisticGyeonggi 2015. Gyeonggi-do. Provinsi Gyeonggi. 2016. Laporan Kebijakan Provinsi Gyeonggi. Gyeonggi-do.

Riska, Ayu Wahyudiya. 2012. Pengaruh Soft Diplomacy dalam Membangun Citra Korea Selatan di Indonesia. (tesis). Universitas Hasanuddin.

Sin Gidong. 2014. A Study on the Curent Conditions of Beauty Industry in GyeonggiDo. Studi dasar 2014-33. Gyeonggi Reseach Institute.

Sugiyono. 2014. Metode Penelitian Kuantitatif, Kualiratif dan R\&D. Bandung: Alfabeta.

Suray Agung Nugroho. 2004. "Hallyu 'Gelombang Korea' di Asia dan Indonesia: 
Trend Merebaknya Budaya Pop Korea”, Makalah dipresentasikan dalam workshop untuk Guru-guru Sekolah di Jawa Tengah, Multimedia Room, Universitas Gajah Mada, April, 2004.

\section{Profil Penulis}

Kang Hyeonseock adalah PNS di Provinsi Gyeonggi, Korea Selatan (Republic of Korea). Dia menyelesaikan Pendidikan Sarjana (Ilmu Hukum) pada tahun 1991 dan Pascasarjana (Magister Ilmu Hukum) pada tahun 1993 di Universitas Dongguk di Seoul, Korea. Sejak tahun 1995, Kang bekerja di Provinsi Gyeonggi (pemerintah daerah) dan Menteri Keamanan \& Administrasi Umum (pemerintah pusat) di bidang audit dan keuangan. Setelah terpilih mendapatkan beasiswa pemerintah Korea untuk belajar di pascasarjana di luar negeri tahun 2014, Kang mengikuti proram BIPA selama lima bulan untuk menyiapkan bahasa Indonesia di Unud, kemudian diterima oleh S2 UNud pada bulan Februari tahun 2015. Email: blst@naver.com 